\title{
Pengaruh Likuiditas dan Efisiensi Keuangan Terhadap Harga Saham Perusahaan Kategori Pariwisata, Restoran, dan Hotel
}

\author{
Dian Kurnianingrum ${ }^{1}$, Nugraha ${ }^{2}$, Maya $\mathrm{Sari}^{3}$ \\ 1,2,3 Universitas Pendidikan Indonesia \\ e-mail: 1dian_k@upi.edu
}

\begin{tabular}{ccc}
\hline Diterima & Direvisi & Disetujui \\
$16-08-2021$ & $11-09-2021$ & $14-09-2021$ \\
\hline
\end{tabular}

\begin{abstract}
Abstrak - Kondisi pandemi Covid-19 cukup memukul kondisi pariwisata Indonesia, namun sektor pariwisata masih memiliki peluang untuk kembali mencapai kondisi puncak dan menjadi penopang bagi pelaku usaha lainnya. Penelitian ini bertujuan untuk mengetahui kondisi likuiditas, efisiensi, dan harga saham dari perusahaan terbuka yang bergerak pada sektor pariwisata, restoran, dan hotel secara keseluruhan. Penelitian ini juga bertujuan untuk mengetahui ada tidaknya pengaruh positif dari kondisi likuiditas dan efisiensi keuangan terhadap harga saham perusahaan. Data diambil pada tahun 2016-2017 pada saat kondisi pariwisata di Indonesia berada dalam keadaan normal, agar bisa menggambarkan perilaku investor pada masa normal. Ada tiga hipotesis yang diuji dalam penelitian ini. Hipotesis pertama Current Ratio (CR) memberikan pengaruh positif atas harga saham. Hipotesis kedua Return on Asset (ROA) memberikan pengaruh positif atas harga saham, dan hipotesis ketiga (H3) adalah Return on Equity (ROA) memberikan pengaruh positif atas harga saham. Berdasarkan data yang dikumpulkan, kondisi likuiditas dan efisiensi dari perusahaan yang bergerak di bidang pariwisata, hotel dan restorant dinilai cukup sehat. Namun, CR, ROA, dan ROE tidak memberikan pengaruh kepada harga saham. Pengaruhnya bahkan dinilai lemah. Sehingga bisa disimpulkan bahwa likuiditas dan efisiensi keuangan tidak mempengaruhi harga saham dari perusahaan kategori pariwisata, restoran, dan hotel. Ada variabel lain yang mempengaruhi harga saham dari industri tersebut.
\end{abstract}

Kata Kunci: efisiensi, harga saham, likuiditas, pariwisata

\begin{abstract}
The Covid-19 pandemic has hit hard Indonesia's tourism sector. However, the tourism sector still can return to its peak conditions and become the support for another business sector. This research aims to determine the condition of liquidity, efficiency, and stock prices of public companies engaged in the tourism, restaurant, and hotel sectors as a whole. This research also aims to determine whether there is a positive influence of liquidity conditions and financial efficiency on the company's stock price. The data was taken in 2016-2017, when tourism conditions in Indonesia were in normal condition, to describe investors' behavior in regular times. There are three hypotheses tested in this study. The first hypothesis is Current Ratio (CR) has a positive influence on stock prices. The second hypothesis is that Return on Assets (ROA) has a positive effect on stock prices, and the third hypothesis is that Return on Equity (ROA) positively impacts stock prices. Based on the data collected, the liquidity and efficiency conditions of companies engaged in tourism, hotels, and restaurants are considered relatively healthy. But, CR, ROA, and ROE do not affect stock prices. Its influence is even regarded as weak. Researchers can conclude that liquidity and financial efficiency do not affect companies' stock prices in tourism, restaurants, and hotels. Other variables affect the stock price of the industry.
\end{abstract}

Keywords: efficiency, liquidity, stock price, tourism

\section{PENDAHULUAN}

Pariwisata memegang peranan penting dalam perekonomian Indonesia. Berdasarkan data, pada tahun 2019 sektor pariwisata menyumbang 4,8\% dari PDB (Produk Domestik Bruto) Indonesia (Lokadata, n.d.). Walaupun hanya menyumbang $4,8 \%$, sektor pariwisata dianggap cukup penting karena sektor tersebut menjadi jangkar bagi para pelaku usaha lainnya termasuk UMKM (Usaha Kecil Menengah) (CNN Indonesia, 2020).

Kondisi pandemi Covid-19 cukup memukul kondisi pariwisata Indonesia, namun sektor pariwisata masih memiliki peluang untuk kembali mencapai kondisi puncak dan menjadi penopang bagi pelaku usaha lainnya. Penelitian ini membahas tentang bagaimana pengaruh likuiditas dan efisiensi keuangan dari perusahaan yang bergerak pada bidang 
pariwisata, restoran, dan hotel terhadap harga saham. Data diambil dari Ringkasan Performa Perusahaan Tercatat yang ada di BEI (Bursa Efek Indonesia) pada tahun 2016-2017 pada saat kondisi pariwisata di Indonesia berada dalam keadaan normal, agar bisa menggambarkan perilaku investor pada masa normal.

Saat kinerja keuangan suatu perusahaan dinilai baik, secara teori hal tersebut mampu memberikan sinyal positif kepada investor. Sebuah sinyal apabila diintepretasikan oleh penerima akan mendorong prilaku tertentu (Connelly et al., 2011). Sinyal positif perusahaan diharapkan mampu menaikkan permintaan akan saham, sehingga harganya meningkat. Namun apabila terjadi asimetri informasi, maka penilaian investor bisa terdistorsi (Cohen \& Dean, 2005).

Penelitian ini bertujuan untuk mengetahui kondisi likuiditas, efisiensi, dan harga saham dari perusahaan terbuka yang bergerak pada sektor pariwisata, restoran, dan hotel secara keseluruhan. Penelitian ini juga bertujuan untuk mengetahui ada tidaknya pengaruh positif dari kondisi likuiditas dan efisiensi keuangan terhadap harga saham perusahaan.

Berdasarkan tujuan di atas rumusan masalah penelitian adalah sebagai berikut: pertama bagaimana kondisi likuiditas, efisiensi, dan harga saham perusahaan terbuka yang bergerak pada sektor pariwisata, restoran, dan hotel. Kedua apakah kondisi likuiditas keuangan perusahaan berpengaruh positif kepada harga saham perusahaan. Dan terakhir, apakah kondisi efisiensi keuangan perusahaan berpengaruh positif kepada harga saham perusahaan.

Pada perusahaan terbuka, investor bisa memahami kinerja perusahaan dengan cara menganalisa laporan keuangan. Laporan keuangan bisa dianalisa dengan menggunakan rasio keuangan. Rasio keuangan menggambarkan hubungan antara dua atau lebih variable keuangan pada waktu yang sama, atau menggambarkan hubungan antara variable keuangan pada waktu yang berbeda (Leach \& Melicher, 2018). Rasio keuangan yang biasa digunakan untuk menilai kinerja perusahaan, yaitu: rasio likuiditas, rasio aktivitas/ periode konversi, rasio rentabilitas/ hutang, rasio profitabilitas dan rasio efisiensi (Leach \& Melicher, 2018). Penelitian ini fokus untuk menilai kinerja dari sisi likuiditas dan efisiensi perusahaan.

Rasio likuiditas menggambarkan kemampuan perusahaan untuk membayar hutang jangka pendeknya dengan asset lancar. Sedangkan rasio efisiensi menggambarkan kemampuan sumber daya yang dimiliki perusahaan dalam menghasilkan keuntungan (Leach \& Melicher, 2018).

Rasio yang biasa digunakan untuk mengalisa likuiditas di perusahaan terbuka adalah current ratio (CR). Current ratio dihitung dengan cara membandingkan harta lancar dengan hutang lancar perusahaan. Rasio tersebut dinilai sehat apabila nilainya lebih besar atau sama dengan satu (Leach \& Melicher, 2018).
Efisiensi perusahaan dalam laporan keuangan yang dipublikasikan, dilambangkan dengan rasio ROA (Return on Asset) dan ROE (Return on Equity). ROA menggambarkan kemampuan harta perusahaan untuk menghasilkan keuntungan. Dan ROE digunakan untuk menggambarkan kemampuan modal perusahaan untuk menghasilkan keuntungan. Nilai ROA dihitung dengan membandingkan laba bersih dengan nilai total harta. Nilai ROE dinilai dengan membandingkan laba bersih dengan total modal perusahaan. Nilai kedua rasio efisiensi ini semakin besar semakin baik (Leach \& Melicher, 2018).

Pengaruh kinerja perusahaan terhadap harga saham pernah diteliti oleh beberapa peneliti lain. Namun penelitian tersebut dilakukan pada kategari perusahaan yang berbeda atau dilakukan pada periode yang berbeda.

Supriadi dkk (2013) meneliti pengaruh Earning per Share (EPS), ROA, Operating Profit Margin (OPM) terhadap harga saham (Supriadi \& Ariffin, 2013). Penelitian ini dilakukan pada rentang tahun 2006-2010 pada perusahaan semen di Indonesia yaitu PT. Indocement Tunggal Prakarsa Tbk. dan PT Holcim Indonesia Tbk. Menurut hasil penelitian OPM di PT. Indocement Tunggal Prakarsa Tbk. berpengaruh signifikan terhadap perubahan harga saham, namun di PT Holcim Indonesia Tbk. OPM tidak memberikan pengaruh signifikan terhadap perubahan harga saham. ROA dan EPS di kedua perusahaan tidak memberikan pengaruh signifikan kepada harga saham, sehingga peneliti menyimpulkan adanya pengaruh eksternal lain yang mempengaruhi harga saham.

A. Rusli, dkk (2014) meneliti pengaruh rasio keuangan (ROA dan ROE) terhadap harga saham pada bank BUMN (Rusli \& Dasar, 2014). Penelitian dilakukan pada periode 2009-2013. Hasilnya ROA memberikan pengaruh signifikan sedangkan ROE tidak memberikan pengaruh yang signifikan.

E. Setiyono, dkk (2016) meneliti pengaruh CR, Debt to Equity Ratio (DER), ROA, EPS dan ukuran perusahaan terhadap return saham di 22 perusahaan property dan real estate yang terdaftar di Bursa Efek Indonesia (BEI) (Setiyono, 2016). Penelitian dilakukan pada tahun 2012-2014. Hasilnya, hanya DER dan EPS yang berpengaruh positif terhadap return saham. Variabel lain tidak memberikan pengaruh.

J. Ponggohong, dkk (2016) meneliti bagaimana kinerja perusahaan mempengaruhi harga saham (Ponggohong et al., 2016). Rasio kinerja yang dijadikan tolak ukur adalah CR, Total Asset Turn Over (TATO), DER, Debt to Asset Ratio (DAR), ROA, dan ROE. Penelitian dilakukan terhadap 16 perusahaan ritel yang terdaftar di BEJ. Dari hasil uji $\mathrm{F}$ diketahui bahwa seluruh variable memberikan pengaruh signifikan terhadap harga saham. Berdasarkan hasil uji t hanya CR, ROA, dan ROE yang memberikan pengaruh signifikan terhadap harga saham. 
L. Pratami Putri (2017) meneliti pengaruh profatibilitas pada harga saham perusahaan tambang batu bara di Indonesia (Putri, 2017). Peneliti menggunakan data ROA dan ROE pada tahun 20102013 dari 10 perusahaan batu bara di Indonesia. Hasil penelitian adalah, ROA dan ROE perusahaan dinilai tidak memberikan pengaruh signifikan kepada harga saham, bahkan kontribusi pengaruhnya dinilai lemah.

Penelitian berjudul "Pengaruh Likuiditas dan Efisiensi Keuangan terhadap Harga Saham Perusahaan Kategori Pariwisata, Restoran, dan Hotel" bertujuan untuk mengetahui apakah likuiditas dan efisiensi perusahaan mampu mempengaruhi harga saham dari perusahaan yang bergerak dalam bidang pariwisata, restoran, dan hotel. Likuiditas dan efisiensi perusahaan seharusnya mampu memberikan sinyal positif kepada investor sehingga harga saham perusahaan meningkat.

Kinerja keuangan perusahaan merupakan salah satu signal yang diberikan kepada investor yang secara teori bisa mempengaruhi harga saham. Pada beberapa penelitian sebelumnya disimpulkan tidak semua variable kinerja keuangan memberikan efek positif pada kenaikan harga saham. Dengan penelitian ini peneliti ingin memastikan bagaimana efek kinerja keuangan terutama kinerja likuiditas dan efisiensi terhadap harga saham perusahaan, terutama perusahaan yang bergerak pada bidang pariwisata, restoran, dan hotel. Sektor pariwisata, restoran, dan hotel adalah salah satu penopang utama PDB (Pendapatan Domestik Bruto) dari Indonesia. Kemajuan di sektor tersebut harus didukung oleh pengelolaan keuangan yang tepat sehingga mampu menjadi industri yang berkelanjutan hingga masa yang akan datang.

\section{METODE PENELITIAN}

Metode penelitian ini adalah kuantitatif. Penelitian ini menguji pengaruh rasio likuiditas keuangan yaitu Current Ratio/ CR (X1), dan rasio efektifitas keuangan yaitu Return on Asset/ ROA (X2) dan Return on Equity/ ROE(X3), pada harga saham (Y). Model persamaan dari penelitian ini adalah model struktural persamaan tunggal. Model strukural persamaan tunggal dianalisa dengan menggunakan analisa regresi data panel.

Data penelitian yang digunakan adalah data panel. Peneliti menggunakan data cross section dan data time series. Data cross section yang digunakan berbentuk data perusahaan yang bergetak di bidang pariwisata, restoran, dan hotel, dan telah listing di Bursa Efek Indonesia (BEI). Data time series yang digunakan adalah nilai rasio $\mathrm{CR}$, ROA, ROE, dan harga saham dari masing-masing perusahaan pada tahun 2016 dan 2017.

Terdapat 21 perusahaan yang bergerak dalam bidang pariwisata, restoran, dan hotel yang memenuhi syarat penelitian. Perusahaan yang diteliti tidak hanya telah listing di BEI namun juga telah mempublikasikan laporan keuangannya pada tahun 2016 dan 2017.

Data rasio dan harga saham dari masingmasing perusahaan diambil dari website BEI. Data diambil pada bulan November 2020 dari Ringkasan Performa Perusahaan Tercatat (Bursa Efek Indonesia, 2020). Harga saham yang diambil adalah harga saham penutup (closing price) pada tanggal 31 Desember pada masing-masing tahun.

Penelitian ini memiliki 3 variabel independen yaitu X1 (CR), X2 (ROA), dan X3 (ROE). Masing-masing independen variable akan diuji pengaruhnya terhadap variable dependent (Y) yaitu harga saham. Berdasarkan uraian tersebut, hipotesis dari penelitiannya ini adalah sebagai berikut:

Metode penelitian ini adalah kuantitatif. Penelitian ini menguji pengaruh rasio likuiditas keuangan yaitu Current Ratio/ CR (X1), dan rasio efektifitas keuangan yaitu Return on Asset/ ROA (X2) dan Return on Equity/ ROE(X3), pada harga saham (Y). Model persamaan dari penelitian ini adalah model struktural persamaan tunggal. Model strukural persamaan tunggal dianalisa dengan menggunakan analisa regresi data panel.

Data penelitian yang digunakan adalah data panel. Peneliti menggunakan data cross section dan data time series. Data cross section yang digunakan berbentuk data perusahaan yang bergetak di bidang pariwisata, restoran, dan hotel, dan telah listing di Bursa Efek Indonesia (BEI). Data time series yang digunakan adalah nilai rasio $\mathrm{CR}$, ROA, ROE, dan harga saham dari masing-masing perusahaan pada tahun 2016 dan 2017.

Terdapat 21 perusahaan yang bergerak dalam bidang pariwisata, restoran, dan hotel yang memenuhi syarat penelitian. Perusahaan yang diteliti tidak hanya telah listing di BEI namun juga telah mempublikasikan laporan keuangannya pada tahun 2016 dan 2017.

Data rasio dan harga saham dari masingmasing perusahaan diambil dari website BEI. Data diambil pada bulan November 2020 dari Ringkasan Performa Perusahaan Tercatat (Bursa Efek Indonesia, 2020). Harga saham yang diambil adalah harga saham penutup (closing price) pada tanggal 31 Desember pada masing-masing tahun.

Penelitian ini memiliki 3 variabel independen yaitu X1 (CR), X2 (ROA), dan X3 (ROE). Masing-masing independen variable akan diuji pengaruhnya terhadap variable dependent (Y) yaitu harga saham. Berdasarkan penelitian sebelumnya, diketahui bahwa Current Ratio memberikan pengaruh pada harga saham perusahaan (Ponggohong et al., 2016). Return on Asset (ROA) dan Return on Equity (ROE) juga memberikan pengaruh terhadap harga saham (Ponggohong et al., 2016; Putri, 2017; Rusli \& Dasar, 2014; Setiyono, 2016). Sehingga bisa diputuskan, hipotesis dari penelitiannya ini adalah sebagai berikut: 
H1 Current Ratio (CR) memberikan pengaruh positif atas harga saham.

H2 Return on Asset (ROA) memberikan pengaruh positif atas harga saham.

H3 Return on Equity (ROE) memberikan pengaruh positif atas harga saham.

Data yang telah dikumpulkan kemudian diolah dengan menggunakan bantuan program statistik eviews 10 agar dapat ditarik kesimpulan apakah independent variable yaitu $\mathrm{CR}$, ROA, dan ROE memberikan pengaruh positif atas variable dependen yaitu harga saham.

\section{HASIL DAN PEMBAHASAN}

Sebagaimana telah dijelaskan sebelumnya, rumusan masalah dari penelitian ini, pertama adalah bagaimana kondisi likuiditas, efisiensi, dan harga saham dari perusahaan terbuka yang bergerak dalam bidang pariwisata, restoran, dan hotel. Kedua adalah bagaimana pengaruh kondisi likuiditas, dan yang ketiga adalah bagaimana pengaruh kondisi efisiensi perusahaan pada harga saham. Beberapa kesimpulan bisa ditarik setelah data dianalisa menggunakan statistik deskriptif dan analisis regresi data panel.

\section{Kondisi Likuiditas dari Perusahaan}

Kondisi likuiditas perusahaan tercermin dari current ratio perusahaan. Current ratio membandingkan nilai harta lancar dengan nilai hutang lancar. Dari rasio ini investor bisa menganalisa kemampuan perusahaan untuk membayar hutang jangka pendeknya. Semakin besar nilai current ratio semakin baik kemampuan perusahaan untuk membayar hutang jangka pendeknya.

Tabel 1 Sebaran Data Penelitian

\begin{tabular}{|c|c|c|c|c|}
\hline \multicolumn{4}{|c|}{ Jumlah Data } & 21 perusahaan \\
\hline \multicolumn{4}{|c|}{ Tahun Observasi } & $2016-2017$ \\
\hline \multicolumn{4}{|c|}{ Jumlah Data Panel } & 42 data \\
\hline & CR & ROA & ROE & $\begin{array}{l}\text { HARGA } \\
\text { SAHAM }\end{array}$ \\
\hline MEAN & 208,69 & 2,70 & 4,75 & $1.057,17$ \\
\hline MAX & 834,56 & 12,72 & 15,99 & $1.300,00$ \\
\hline MIN & 48,24 & $-1,74$ & 2,56 & 50,00 \\
\hline
\end{tabular}

Berdasarkan data dari tabel 1 bisa disimpulkan bahwa perusahaan yang bergerak di bidang pariwisata, restoran dan hotel memiliki proporsi current ratio yang cukup baik. Nilai minimum dari CR perusahaan adalah 48,24 dengan rata-rata CR 208,69. Artinya perusahaan dalam kategori ini minimum memiliki harta lancar 48,24 kali lebih banyak dari pada hutang lancarnya. Perusahaan dalam kategori ini rata-rata ternyata, memegang harta lancar sebanyak 208,69 kali lebih banyak dari hutang lancarnya. Bahkan berdasarkan data, nilai CR tertinggi ada pada angka 834,56 artinya perusahaan tersebut memegang harta lancar 834,56 kali lebih banyak dari pada hutang lancarnya.

Data tersebut menandakan, perusahaan yang bergerak pada bidang pariwisata, resatauran, dan hotel, rata-rata hanya memiliki jumlah harta lancar yang lebih banyak dibandingkan hutang jangka pendeknya.

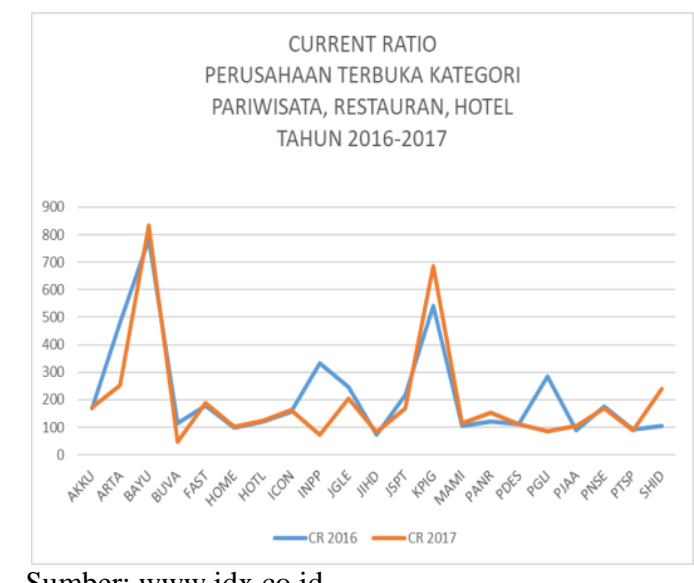

Sumber: www.idx.co.id

Gambar 1. Current Ratio dari Perusahaan

\section{Kondisi Efisiensi dari Perusahaan}

Kondisi efisiensi perusahaan dicerminkan oleh nilai Return on Asset dan Return on Equity. ROA menggambarkan kemampuan asset perusahaan untuk menghasilkan keuntungan, sedangkan ROE memberikan informasi tentang kemampuan modal perusahaan untuk menghasilkan keuntungan.

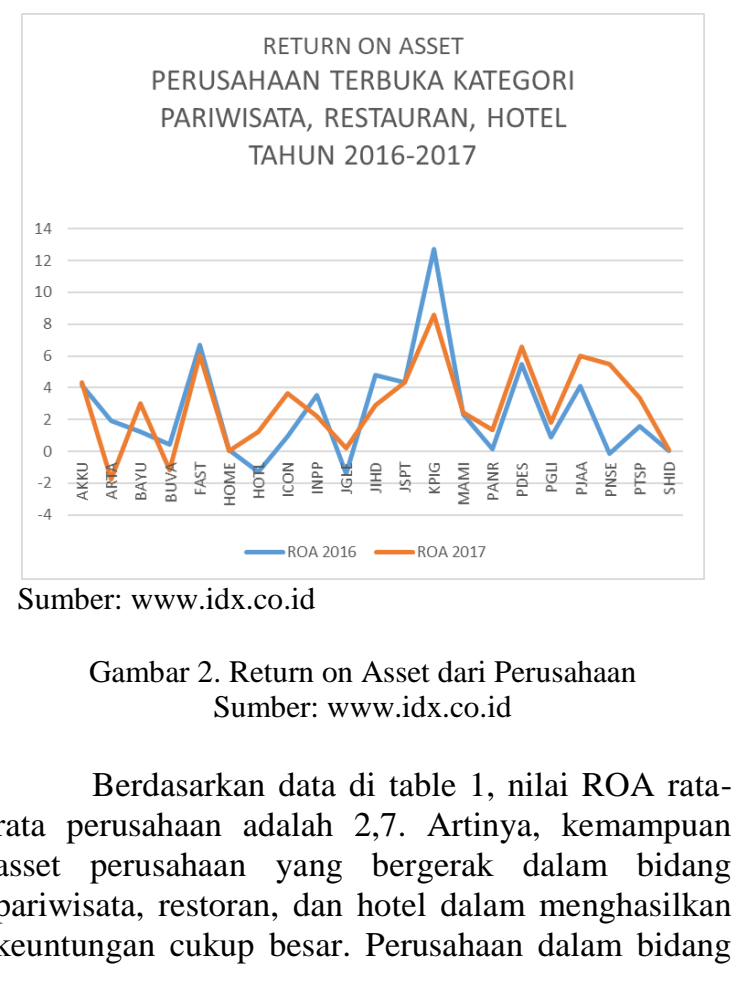


tersebut rata-rata bisa menghasilkan keuntungan 2,7 kali lipat dari asset. Walaupun beberapa perusahaan mencatat kerugian pada rentang tahun 2016-2017, namun jumlah perusahaan yang mengalami kerugian tersebut tidak banyak.

Berdasarkan table 1, Nilai ROE rata-rata perusahaan yang bergerak dalam bidang pariwisata, restoran, dan hotel adalah 4,75. Artinya modal yang dimiliki perusahaan bisa menghasilkan keuntungan sebanyak 4,75 kali lipat. Nilai minimum ROE adalah -2,56. Nilai minus menggambarkan adanya perusahaan yang mengalami kerugian. Berdasarkan gambar 3 ada dua perusahaan yang mengalami kerugian pada tahun 2016 dan ada dua perusahaan yang mengalami kerugian pada tahun 2017.

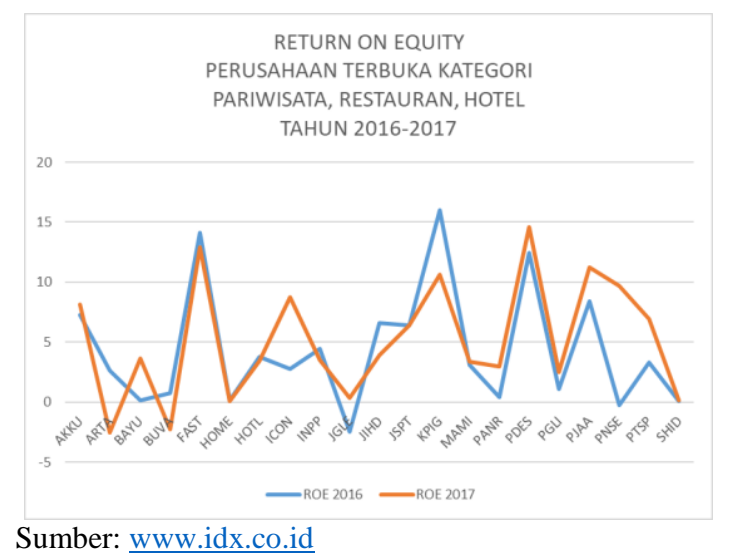

Gambar 3. Return on Equity dari Perusahaan

\section{Kondisi Harga Saham Perusahaan}

Harga saham perusahaan terendah adalah 50 rupiah, yaitu saham PT. Mas Murni Indonesia Tbk. (MAMI) pada tahun 2016. Harga saham tertinggi adalah 7.300 rupiah, yaitu saham tahun 2016 milik PT. Pioneerindo Gourmet International Tbk. (PTSP). Harga saham rata-rata perusahaan yang bergerak dalam bidang pariwisata, restoran dan hotel adalah $1.057,17$ rupiah.

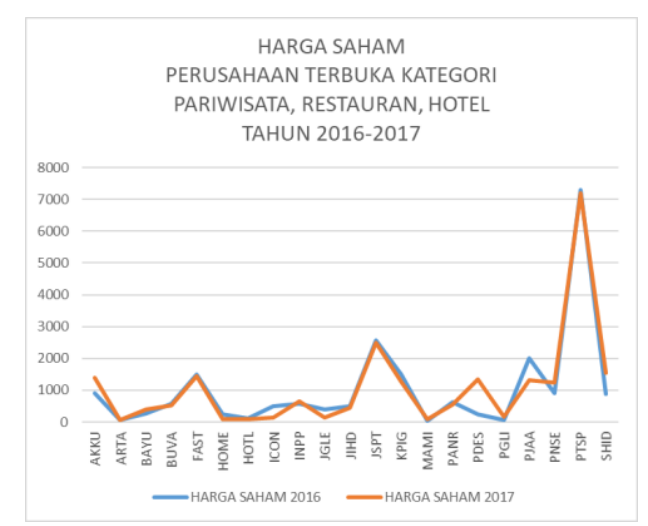

Sumber: www.idx.co.id

Gambar 4. Harga Saham dari Perusahaan Sumber: www.idx.co.id

Berdasarkan analisa likuiditas, efisiensi, dan harga saham bisa disimpulkan bahwa rata-rata kondisi keuangan perusahaan yang bergerak pada bidang pariwisata, restoran dan hotel dinilai baik. Rata-rata perusahaan memiliki nilai likuiditas yang cukup tinggi. Perusahaan dalam kategori tersebut juga dinilai efisien, karena kemampuannya asset dan modal untuk menghasilkan keuntungan cukup besar. Proporsi keuntungan yang tinggi itulah yang memungkinkan perusahaan memiliki jumlah asset lancar yang cukup banyak dan harga saham yang cukup tinggi, walaupun butuh penelitian lebih lanjut untuk membuktikan pernyataan tersebut.

\section{Pengaruh likuiditas dan efisiensi pada harga saham perusahaan}

Kerangka berfikir dari penelitian ini disajikan pada gambar 5. Untuk memahami pengaruh likuiditas dan efisiensi dari keuangan perusahaan terhadap harga saham, peneliti menggunakan analisis statistik regresi data panel. Likuiditas keuangan dilihat dari nilai CR sebagai variable independen X1. Efisiensi keuangan perusahaan dilihat dari ROA sebagai variable independen X2, dan ROE sebagai variable independen X3. Harga saham merupakan variabel dependen Y. Kemudian dari hasil analisa statistik diuji apakah hipotesis penelitian diterima atau ditolak.

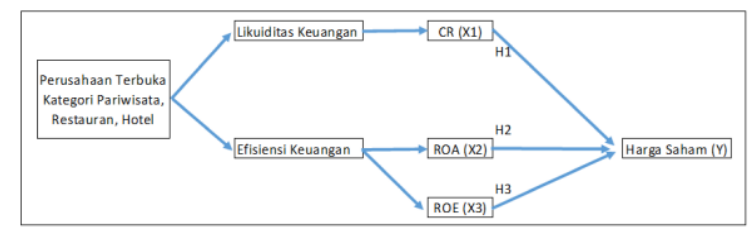

Gambar 5. Kerangka Pemikiran Penelitian

Data yang digunakan sebagai dasar analisa merupakan data panel dimana nilai X1, X2, X3, dan $\mathrm{Y}$ diambil dari data masing-masing perusahaan kategori pariwisata, restoran, dan hotel yang terdaftar di BEI dan masuk dalam kriteria penelitian pada tahun 2016-2017.

Langkah awal yang dilakukan untuk menganalisa data dengan regresi data panel adalah menentukan model estimasi terbaik dengan melakukan uji Chow, Lagrange Multiplier, dan Hausman Test terhadap data. Dari hasil ketiga uji tersebut diputuskan bahwa Common Effect Model adalah model estimasi terbaik dari penelitian ini.

Tabel 2 menunjukkan hasil olahan data penelitian dengan menggunakan bantuan program eviews. Dengan menggunakan derajat tingkat kesalahan sebesar 5\%, bisa disimpulkan sebagai berikut: yang pertama CR tidak memiliki hubungan yang signifikan dengan harga saham. Nilai $p$ value dari CR adalah 0,2497, nilainya lebih besar dari batas kritis yaitu 0,05. Karenanya H1 dari penelitian ditolak. Yang kedua ROA memiliki nilai $\mathrm{p}$ value sebesar 0,0882. Nilainya lebih besar dari batas kritis yaitu 0,05 , sehingga $\mathrm{H} 2$ juga ditolak. ROA tidak memberikan pengaruh pada harga saham. Yang ketiga, nilai ROE juga dinilai tidak mempengaruhi 
harga saham. Nilai p value dari ROE adalah 0,6271 , lebih besar dari titik kritis 0,05. Kesimpulannya H3 dari penelitian juga ditolak.

\begin{tabular}{|c|c|c|c|c|}
\hline \multicolumn{5}{|c|}{$\begin{array}{l}\text { Dependent Variable: HRGSAHAM } \\
\text { Method: Panel Least Squares } \\
\text { Date: } 12 / 28 / 20 \text { Time: } 09: 55 \\
\text { Sample: } 20162017 \\
\text { Periods included: } 2 \\
\text { Cross-sections included: } 21 \\
\text { Total panel (balanced) observations: } 42\end{array}$} \\
\hline Variable & Coefficient & Std. Error & t-Statistic & Prob. \\
\hline $\begin{array}{c}\text { C } \\
\text { CR } \\
\text { ROA } \\
\text { ROE }\end{array}$ & $\begin{array}{r}2.675300 \\
-0.346682 \\
1.437232 \\
-0.253451\end{array}$ & $\begin{array}{l}0.639095 \\
0.296551 \\
0.821430 \\
0.517503\end{array}$ & $\begin{array}{r}4.186077 \\
-1.169049 \\
1.749672 \\
-0.489758\end{array}$ & $\begin{array}{l}0.0002 \\
0.2497 \\
0.0882 \\
0.6271\end{array}$ \\
\hline $\begin{array}{l}\text { R-squared } \\
\text { Adjusted R-squared } \\
\text { S.E. of regression } \\
\text { Sum squared resid } \\
\text { Log likelihood } \\
\text { F-statistic } \\
\text { Prob(F-statistic) }\end{array}$ & $\begin{array}{r}0.224780 \\
0.163579 \\
0.503255 \\
9.624095 \\
-28.65402 \\
3.672790 \\
0.020360\end{array}$ & \multicolumn{2}{|c|}{$\begin{array}{l}\text { Mean dependent var } \\
\text { S.D. dependent var } \\
\text { Akaike info criterion } \\
\text { Schwarz criterion } \\
\text { Hannan-Quinn criter. } \\
\text { Durbin-Watson stat }\end{array}$} & $\begin{array}{l}2.709522 \\
0.550270 \\
1.554953 \\
1.720446 \\
1.615613 \\
0.572347\end{array}$ \\
\hline
\end{tabular}

Gambar 6. Ringkasan Regresi Data Panel Model Comment Effect

Nilai R-squared dari perusahaan adalah sebesar 0,22478. Artinya kemampuan variable prediktor yaitu CR, ROA, dan ROE untuk menjelaskan variable respon yaitu harga saham, hanya $22,478 \%$. Nilai tersebut dinilai lemah. Karena ada 77,522 \% variabel lain yang tidak diteliti mempengaruhi harga saham.

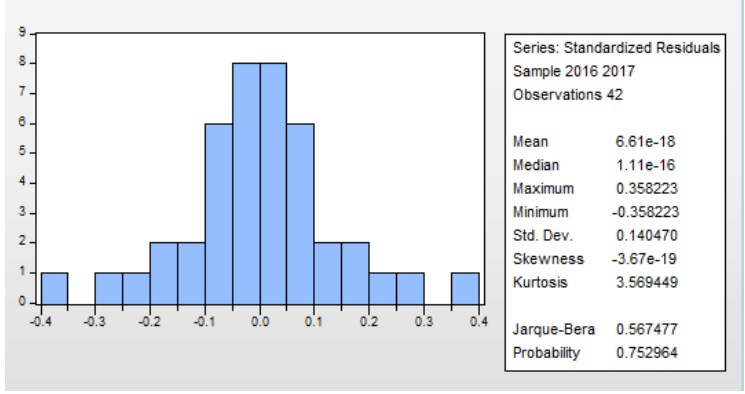

Gambar 7. Uji Normalitas

Berdasarkan hasil tes normalitas data dengan menggunakan Eviews yang tertera pada gambar 6, diketahui nilai probabilitas adalah 0,752964 nilai tersebut lebih besar dari 5 persen. Data penelitian dinilai normal.

Kesimpulan yang bisa diambil dari hasil pengolahan data dengan menggunakan analisa regresi data panel adalah: pada perusahaan terbuka yang bergerak pada bidang pariwisata, restoran, dan perhotelan, likuiditas dan efisiensi dari keuangan perusahaan ternyata tidak memberikan pengaruh yang signifikan terhadap harga saham. Bahkan pengaruhnya dinilai lemah. Ada variabel lain yang tidak diteliti mampu mempengaruhi harga saham.

\section{KESIMPULAN}

Sektor pariwisata, walau saat ini sedang dalam kondisi terpukul, namun tetap memiliki potensi untuk kembali berkembang dan menjadi jangkar bagi bisnis-bisnis lainnya. Penelitian ini meneliti bagaimana salah satu sinyal perusahaan yaitu laporan keuangan mempengaruhi harga saham perusahaan yang bergerak pada bidang pariwisata, restoran, dan hotel. Penelitian ini dilakukan pada periode 20162017 di saat kondisi perekonomian normal pada perusahaan kategori pariwisata, restoran, dan hotel terbuka yang listing di BEI. Diharapkan hasil dari penelitian ini bisa menggambarkan perilaku investor dimasa normal.

Penelitian ini fokus meneliti pengaruh likuiditas dan efisiensi keuangan perusahaan pada harga saham. Likuiditas keuangan dinilai dengan menggunakan current ratio, sedangkan efisiensi keuangan dinilai dengan menggunakan Return on Asset dan Return on Equity. Data yang dikumpulkan dianalisa dengan menggunakan analisa regresi data panel.

Berdasarkan data yang dikumpulkan, pertama peneliti bisa menarik kesimpulan tentang kondisi likuiditas dan efisiensi keuangan dari perusahaan yang bergerak pada bidang pariwisata, restoran, dan hotel. Dilihat dari sisi likuiditas, rata-rata perusahaan pada kategori ini ternyata memiliki harta lancar yang lebih besar daripada hutang lancarnya. Dilihat dari sisi efisiensi, perusahaan tenyata mampu memanfaatkan harta dan modal yang dimiliki untuk menghasilkan keuntungan. Ada beberapa perusahaan yang mengalami kerugian pada tahun 2016 dan 2017, namun nilai rata-rata dari ROA dan ROE perusahaan masih cukup besar. Berdasarkan uraian tersebut bisa disimpulkan bahwa kondisi likuiditas dan efisiensi dari perusahaan yang bergerak di bidang pariwisata, hotel dan restoran cukup sehat.

Kesimpulan kedua berhubungan dengan pengaruh likuiditas dan efisiensi keuangan terhadap harga saham. Ada tiga hipotesis yang diuji dalam penelitian ini. Hipotesis pertama (H1) Current Ratio (CR) memberikan pengaruh positif atas harga saham. Hipotesis kedua (H2) Return on Asset (ROA) memberikan pengaruh positif atas harga saham, dan Hipotesis ketiga (H3) adalah Return on Equity (ROA) memberikan pengaruh positif atas harga saham.

Berdasarkan hasil analisa regresi data panel dengan menggunakan bantuan program eviews, ditarik kesimpulan bahwa CR, ROA, dan ROE tidak memberikan pengaruh kepada harga saham. Pengaruhnya bahkan dinilai lemah. Dari hasil perhitungan R-squared disimpulkan bahwa harga saham $77,522 \%$ ditentukan oleh variabel lain yang tidak diteliti dalam penelitian ini.

Data yang bisa dikumpulkan oleh peneliti terbatas. Data yang tersedia dalam situs BEI adalah data periode beberapa tahun kebelakang. Data terakhir dan terlengkap yang bisa peneliti dapatkan adalah data tahun 2017 .

Berdasarkan hasil penelitian ada beberapa research gap yang bisa dijadikan dasar bagi penelitian selanjutnya. Pertama berkaitan dengan keterbaruan data dan jumlah data, penggunaan data yang lebih 
banyak dan baru memungkinkan hasil yang lebih menggambarkan kondisi sebenarnya.

Gap lain berhubungan dengan penelitian lanjutan untuk menemukan variabel-variabel penentu harga saham. Sebagaimana telah dijelaskan sebelumnya, kondisi likuiditas dan efisiensi keuangan perusahaan hanya memberikan kontribusi sebesar $22,478 \%$ terhadap harga saham.

\section{REFERENSI}

Bursa Efek Indonesia. (2020, November 20). PT Bursa Efek Indonesia. IDX. https://www.idx.co.id/data-pasar/laporanstatistik/ringkasan-performa-perusahaantercatat/

CNN Indonesia. (2020, February 26). Menghitung Kontribusi Sektor Pariwisata Bagi Ekonomi RI. CNN Indonesia. https://www.cnnindonesia.com/ekonomi/2020 0226121314-532-478265/menghitungkontribusi-sektor-pariwisata-bagi-ekonomi-ri

Cohen, B. D., \& Dean, T. J. (2005). Information asymmetry and investor valuation of IPOs: Top management team legitimacy as a capital market signal. Strategic Management Journal, 26(7), 683-690. https://doi.org/10.1002/smj.463

Connelly, B. L., Certo, S. T., Ireland, R. D., \& Reutzel, C. R. (2011). Signaling Theory: A Review and Assessment. Journal of Management, 37(1), 39-67. https://doi.org/10.1177/0149206310388419

Leach, J. C., \& Melicher, R. W. (2018). Entrepreneurial Finance (6th ed.). Cengage. https://www.amazon.com/EntrepreneurialFinance-J-Chris-Leach-ebook-dpB01N9ILT0F/dp/B01N9ILT0F/ref=mt_other? _encoding $=$ UTF8 \&me $=\&$ qid $=$

Lokadata. (n.d.). Kontribusi pariwisata terhadap PDB, 2010-2019 - Lokadata. Retrieved December 19, 2020, from https://lokadata.beritagar.id/chart/preview/kont ribusi-pariwisata-terhadap-pdb-2010-20191582001327

Ponggohong, J. O., Murni, S., Mangantar, M., Manajemen, J., \& Ekonomi dan Bisnis, F. (2016). Pengaruh Kinerja Keuangan Terhadap Harga Saham (Studi Pada Perusahaan Ritel Yang Terdaftar Di Bei Tahun 2010-2013) The Effect Of Financial Performance On Share Price (Study On Retail Companies Listed On The Idx Year 2010-2013). Jurnal Berkala Ilmiah Efisiensi, 16(01). https://ejournal.unsrat.ac.id/index.php/jbie/arti cle/view/12052

Putri, L. P. (2017). Pengaruh Profitabilitas Terhadap Harga Saham Pada Perusahaan Pertambangan Batubara Di Indonesia. Jurnal Ilmiah Manajemen Dan Bisnis, 16(2). http://jurnal.umsu.ac.id

Rusli, A., \& Dasar, T. (2014). Pengaruh Rasio Keuangan Terhadap Harga Saham Pada Perusahaan Bumn Perbankan Yang Terdaftar Di Bursa Efek Indonesia. Jurnal Akuntansi STIE Muhammadiyah Palopo, 1(2). www.idx.co.id.

Setiyono, E. (2016). Pengaruh Kinerja Keuangan Dan Ukuran Perusahaan Terhadap Return Saham Lailatul Amanah Sekolah Tinggi Ilmu Ekonomi Indonesia (STIESIA) Surabaya. Jurnal Ilmu Dan Riset Akuntansi (JIRA), 5(5). http://jurnalmahasiswa.stiesia.ac.id/index.php/j ira/article/view/329

Supriadi, Y., \& Ariffin, M. (2013). Pengaruh Kinerja Keuangan Terhadap Harga Saham. Jurnal Ilmiah Manajemen Kesatuan, 1(1), 53-68. https://doi.org/10.37641/jimkes.v1i1.254 